\title{
An Analysis of Dominant Working Styles in Different Professions in Macedonia
}

\author{
(C) 2013 Marina Pavlovska
}

\begin{abstract}
A convenience sample of 90 employees working as Economists, Legal Advisors or IT Experts within three companies in Skopje, Macedonia completed the Working Styles Questionnaire (Hay 1992) and it was found that there were statistically significant differences in working style preferences between the professions. These differences are discussed in relationship to the National Nomenclature of Professions of Macedonia (State Statistical Office 2011) and implications for human resources management are briefly reviewed. Limitations are identified relating to the size and specific location of the subjects. It is concluded that the hypothesis that there will be differences between dominant working styles of the professions is accepted. An explanation is included which clarifies the distinction between drivers (Kahler \& Capers 1974, Kahler 1975, 2008) and working styles (Hay \& Williams 1989, Hay 1993, 2009).
\end{abstract}

\section{Key words}

Working Styles, Drivers, Professions, Economist, Legal Advisor, IT Expert, Human Resource Management, Transactional Analysis

\section{Introduction}

The study reported here is an investigation into the presence of working styles (Hay \& Williams 1989, Hay 1993/2009) using the Working Styles Questionnaire (Hay 1992) which was developed as part of Hay's work on positioning working styles as the healthy expression of drivers (Kahler \& Capers 1974, Kahler 1975, 2008). Participants who were due to attend training programmes being run by the author and the consultant were invited to voluntarily complete the questionnaires and the results were analysed to identify variations in working styles between the professions of Economist, Legal Advisor and IT Expert.

Kahler and Hay, writing as above about drivers and working styles respectively, both comment on how each has its own specific characteristics, such as orientation from or toward people, behavioural indicators (words, voice, posture, facial expressions and gestures), preferred styles of social interaction in contact, positive and negative characteristics, specific reactions to problems and stress, etc. Hay acknowledges that her work was based on the early work of Kahler but stresses that she opted for a focus on healthy functioning rather than pathology. She explains that working styles are positive manifestations of an unconscious set of behaviours learned in early childhood.

\section{Clarification of concepts}

Kahler (Kahler \& Capers 1974) introduced the five drivers; in Kahler (2008) he described how he had developed them through watching videotapes for several weeks during 1971 and that he had named them drivers after Freud's drive, or basic instinct, to repetitive behaviour. Kahler (1975) described drivers as "behaviours that last from a split-second to no more than seven seconds" (p.280). Gellert (1975) suggested that there were more drivers than Kahler had identified. Mescavage \& Silver (1977) proposed, based on a sample of 194 cases, that there were only three drivers. Tudor (2008) proposed the existence of a sixth driver.

An early reference to positive drivers was made by Klein (1987). Hay (Hay \& Williams 1989) also began to focus on the positive aspects of drivers and introduced the term 'working styles' as a label for these. Clarkson (1992) then also wrote about the positive qualities of drivers. Hay (1992, 1993/2009) introduced a Working Styles Questionnaire that reflected the concept of working styles being the ways in which drivers were often regarded as strengths within organisational settings, particularly when they were within the conscious awareness of the individual rather than being subconscious attempts to get recognition from others; the questionnaire also reflects that the strengths come with some pitfalls. 


\section{Professions}

The professions of Economist, Legal Advisor and IT Expert included in this research are defined in accordance with the National Nomenclature of Professions of Macedonia (hereinafter referred to as NNPM), published by the State Statistical Office (2011) of the Republic of Macedonia (translated by the author).

The Economist, single group coding 2631, is defined as: "Economists conduct research, control data, analyse information and prepare reports and plans for solving existing economical and business problems, develop models for analysis, explanation and prediction of economic movements and models. They advise business-economic or other groups, and government, how to formulate solutions for existing and predicted economical and business problems."

Legal Advisor, single group coding 2611, is defined as: "Legal Advisors give legal advice to clients, prepare legal documents, represent the clients before administrative boards and tribunals, defend cases and prosecute in legal courts and give instructions how to defend (appeal) in higher courts."

IT Experts, single group coding 25, is defined as: "Experts for information and communication technology conduct research, plan, design, test, update and develop rules and operational methods in order to improve systems of information and communication technology and concepts about specific applications, programs, databases, etc. in order to achieve optimal performance and data security."

\section{Previous Empirical Research}

Ohlsson (2010) listed 326 researches all conducted or approved by researchers trained for scientific research. These studies generally show scientific evidence of the positive impact of the theory of transactional analysis and its methods in several areas of applicability, although most are about psychotherapeutic application of theory, with only $5 \%$ related to issues associated with its organisational application. Of these, none are related to working styles as the concept.

Kahler (1974) identified five drivers, and developed it (Kahler 1979) by connecting it to other concepts of transactional analysis in a complex theory of personality which he called the Process Model. Later Kahler (1982) adapted the Process Model for organisational application and named it Process Communication Model (PCM). He developed a corresponding questionnaire (Personal Pattern Inventory, PPI) to determine personality types and his website (Kahler 2013) gives details of various studies. However, the foregoing were generally in educational settings.

\section{Research Questions}

The objective of this research is to investigate the prevalence of working styles in the professions in Macedonia of Economist, Legal Advisor, and IT Expert. The questions this research is aiming to answer are:

1. What are the dominant working styles in the selected professions in Macedonia?

2. Is there a difference between their dominant working styles?

3. What are the implications of working styles regarding the management of human resources?

\section{Methodology}

A convenience sample was used in the research, consisting of 90 employees from 3 organizations in Skopje, Macedonia. All were due to attend communication trainings to be conducted by the author and the consultant to the research. They were employed as Economists, Legal Advisors or IT Experts and their job descriptions were in accordance with the job descriptions in the NNPM.

Only gender and occupation were noted; with hindsight it might have been useful to have collected data on length of time in profession.

Table 1. The sample

\begin{tabular}{c|cc|cccc}
\hline & \multicolumn{2}{c}{ Economists } & \multicolumn{2}{c}{$\begin{array}{c}\text { Legal } \\
\text { Advisors }\end{array}$} & \multicolumn{2}{c}{ IT Experts } \\
\hline male & 10 & $33 \%$ & 15 & $50 \%$ & 23 & $77 \%$ \\
& & & & & & \\
\hline female & 20 & $67 \%$ & 15 & $50 \%$ & 7 & $23 \%$ \\
\hline$\Sigma$ & 30 & $33 \%$ & 30 & $33 \%$ & 30 & $33 \%$ \\
\hline
\end{tabular}

The dominant working styles were identified using the Working Styles Questionnaire (WSQ) by Hay (1992). Each of the working styles can occur with intensity from 0 to 40 . The working styles with the highest scores were taken into consideration during the interpretation of the results as the first or the first two highest scores are considered primary dominant working styles while the next highest is the secondary dominant working style.

The questionnaire was translated by the author. A pilot research was conducted prior to the main research as this questionnaire was not standardized for the Macedonian population or language. The pilot research was made with 15 participants ( 5 employees from each of the 3 professions) and no major changes were made to the questionnaire. 
The participants completed the questionnaire voluntarily, within their organisations, in the period FebruaryDecember 2011. Participants were seated in groups, and were given unlimited time to complete paper copies of the questionnaire; they usually took $30-40$ minutes.

Tests were scored by the author and consultant, and participants were given the results in a written report that contained a graphic presentation and short commentary.

\section{Results}

Analysis of the differences between the working styles in the three professions

As shown in Figures 1 \& 4, for Economists Please People and $\mathrm{Be}$ Perfect are primary dominant working styles while Try Hard is a secondary dominant working style.

As shown in Figures 2 \& 4, for Legal Advisors Please People is a primary dominant working style and $\mathrm{Be}$ Perfect is a secondary dominant working style.

As shown in Figures 3 \& 4, for IT Experts Be Perfect could be identified as a primary dominant working style and Please People is a secondary dominant working style.

In Table 2, the basic descriptive statistics are shown in groups and in Figure 4 the differences in the dominant working styles between different professions are clearly noticeable. During the initial interpretation we looked at overlapping of line segments; below the significance of the differences between dominant working styles is more precisely calculated using t-test.

Analysis of the main descriptive statistics The t-test, as a statistical method for determining the significance of differences between arithmetic means, was used for analysing the differences between the research variables. Because the total number of examinees is smaller than 100 , the formula for calculating the significance of differences between arithmetic means of small and independent samples was used to calculate the significance of differences between arithmetic means.

The t-test statistical indicator can be used only if it is proven that the variances of the two groups are homogenous. That can be determined by calculating the F statistic which, if not above the critical value of a certain number of degrees of freedom, indicates that the t-test can be used. Otherwise, a modified formula for calculating the t-test which does not assume equality between variances should be used.

To determine if there is statistically significant difference between different professions in relation to the presence of the five working styles, a comparison of the differences between arithmetic means of each working style in each profession using the t-test is shown in the following.
Hurry Up

As indicated in Table 3, for Hurry Up, statistic F does not exceed the critical value for 58 degrees of freedom at the level of $95 \%$, i.e. $p>0.05$, for all three combinations of groups, which indicates that the variance of the groups is homogenous and t-test can be used.

The values of the t-tests indicate that a statistically significant difference is not found between the arithmetic means of the employees in the professions Economists and Legal Advisors, and between the employees in the professions IT Experts and Legal Advisors $(\mathrm{t}=0.89$, $\mathrm{df}=$ $58, p>0.05 ; t=1.09$, df $=58, p>0.05$ ). Statistically significant difference was found between the arithmetic means between employees in the professions Economists and IT Experts $(t=2.12, d f=58, p<0.05)$.

\section{Be Perfect}

As shown in Table 4, for Be Perfect statistic F does not exceed the critical value for 58 degrees of freedom at the level of $95 \%$, i.e. $p>0.05$, for all three combinations of groups, which indicates that the variance of the groups is homogenous and t-test can be used.

The values of the t-tests indicate that a statistically significant difference was found between the arithmetic means of the employees in the professions Economists and Legal Advisors, and between the employees in the professions Economists and IT Experts $(\mathrm{t}=2.04, \mathrm{df}=58$, $p<0.05 ; t=1.85, d f=58, p<0.05)$. Statistically significant difference was not found between the arithmetic means between employees in the professions Legal Advisors and IT Experts $(t=0.39, d f=58, p>0.05)$.

\section{Please People}

As shown in Table 5, for Please People statistic F does not exceed the critical value for 58 degrees of freedom at the level of $95 \%$, i.e. $p>0.05$, for all three combinations of groups, which indicates that the variance of the groups is homogenous and t-test can be used.

The values of the t-tests indicate that a statistically significant difference was found between the arithmetic means of the employees in the professions Economists and Legal Advisors, between the employees in the professions IT Experts and Legal Advisors and between Economists and IT Experts $(t=1.86, d f=58, p<0.05$; $\mathrm{t}=2.47, \mathrm{df}=58, \mathrm{p}<0.01 ; \mathrm{t}=4.41, \mathrm{df}=58, \mathrm{p}<0.01)$.

\section{Try Hard}

Table 6 for Try Hard indicates that statistic F does not exceed the critical value for 58 degrees of freedom at the level of $95 \%$, i.e. $p>0.05$, for the combinations of the groups Economists and Legal Advisors and Economists and IT Experts, which indicates that the variance of the groups is homogenous and t-test can be used. However, in the combinations of the groups Legal Advisors and IR experts Statistic $F$ exceeds the critical value for 58 degrees of freedom at the level of $99 \%$, i.e. $p<0.01$, indicating that the variance is heterogeneous so the 
Figure 1. Presence of the five working styles in the profession Economist

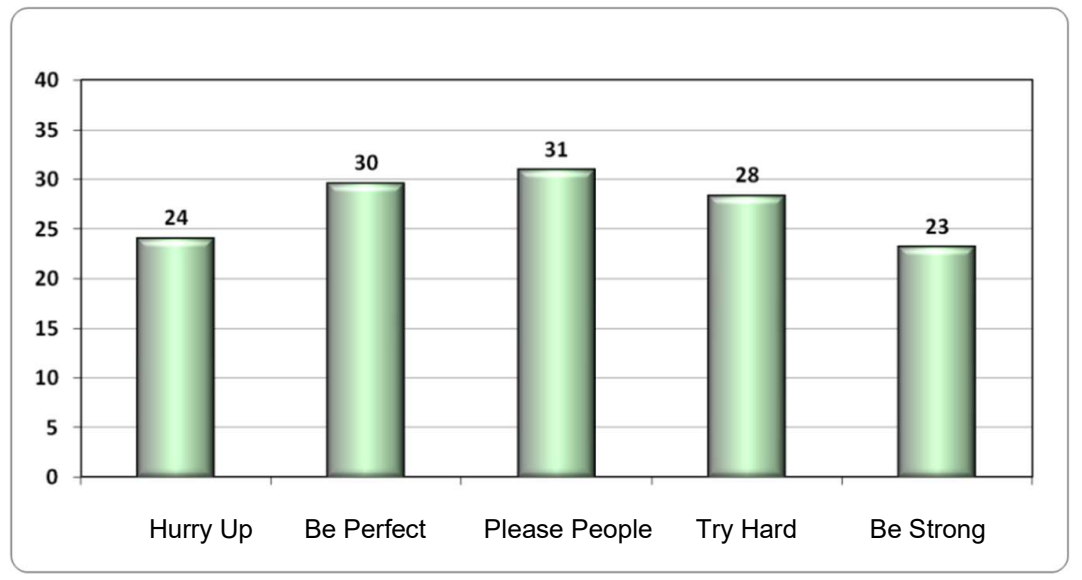

Figure 2. Presence of the five working styles in the profession Legal Advisor

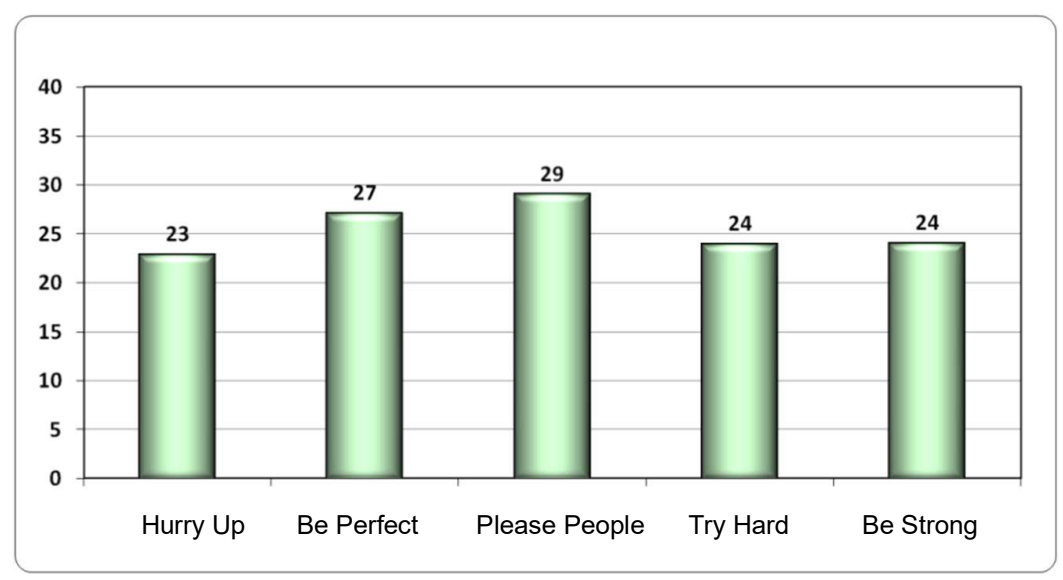

Figure 3. Presence of the five working styles in the profession IT Expert

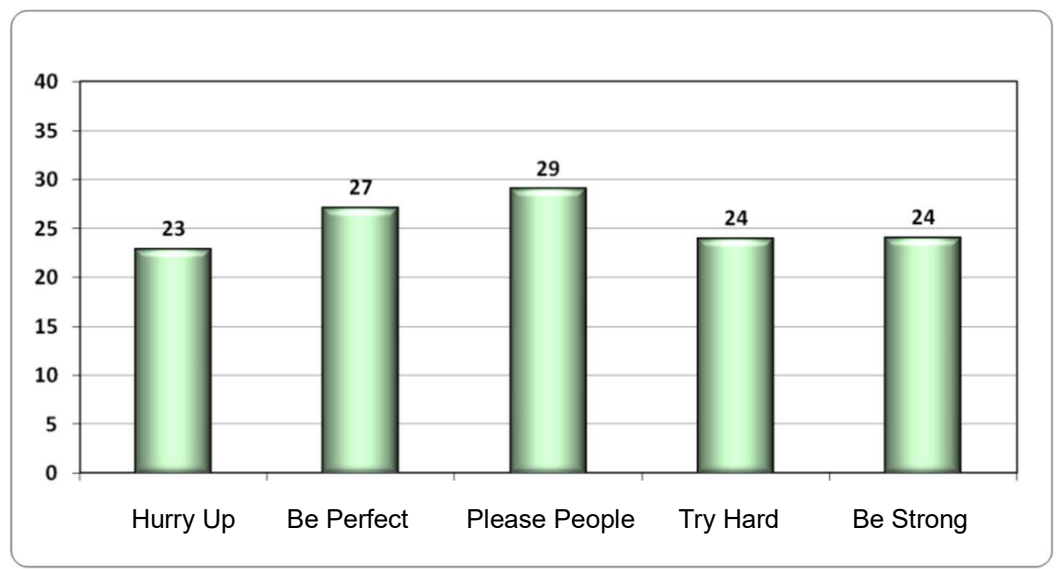


Table 2. Main descriptive statistics of the variables Working styles and Professions

\begin{tabular}{cc|c|c|c}
\hline Working style & & Economists & Legal Advisors & IT Experts \\
\hline Hurry Up & N & 30 & 30 & 30 \\
\hline & M & 24 & 23 & 22 \\
\hline & SD & 4.84 & 5.03 & 3.88 \\
\hline Be Perfect & N & 30 & 30 & 30 \\
\hline & M & 30 & 27 & 28 \\
\hline Please People & SD & 4.41 & 5.06 & 4.11 \\
\hline & N & 30 & 30 & 30 \\
\hline & M & 31 & 29 & 27 \\
\hline Try Hard & SD & 3.99 & 3.94 & 3.56 \\
\hline & N & 30 & 30 & 30 \\
\hline & M & 28 & 24 & 26 \\
\hline Be Strong & SD & 4.85 & 5.82 & 3.4 \\
\hline & N & 30 & 30 & 30 \\
\hline & M & 23 & 24 & 24 \\
\hline & SD & 4.46 & 4.37 & 3.67 \\
\hline
\end{tabular}

Figure 4. Confidence interval error bars

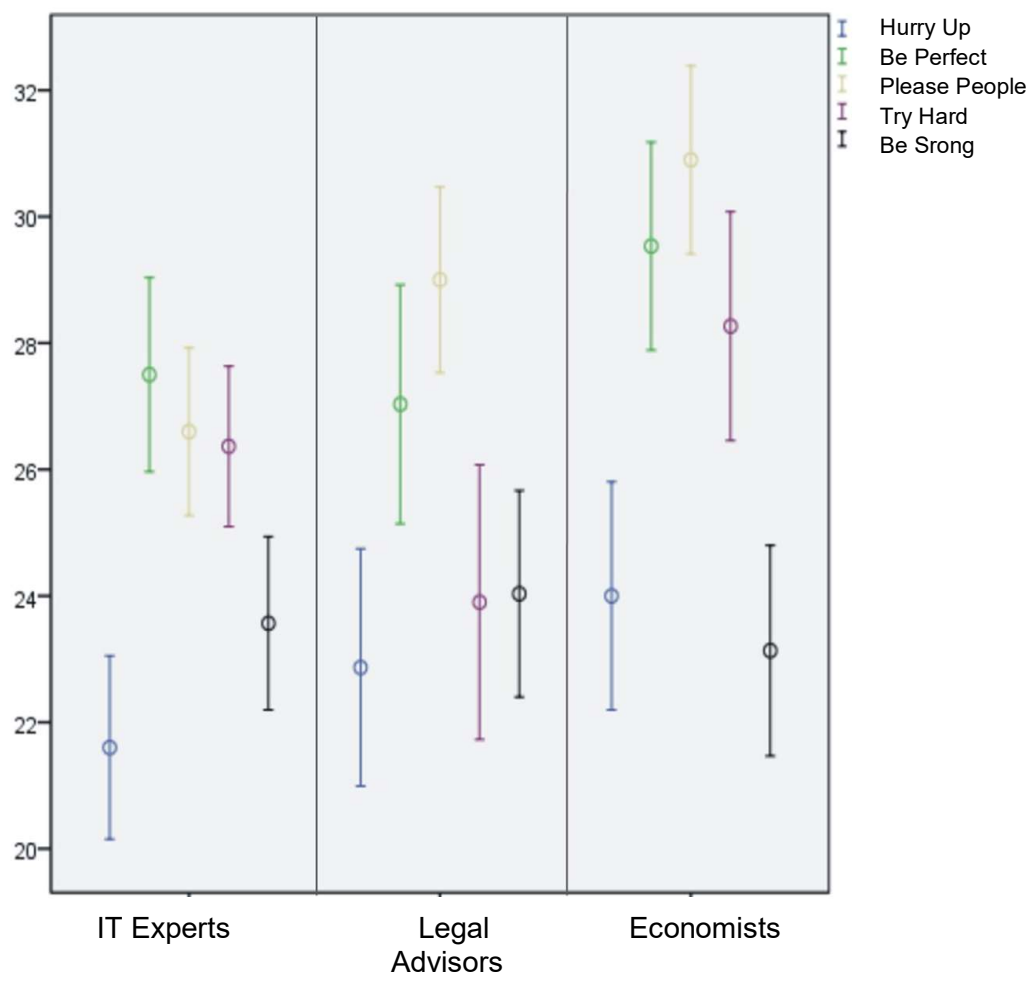


Table 3: Analysis of the differences between the three professions regarding the working style Hurry Up

\begin{tabular}{|c|c|c|c|c|c|c|c|c|c|c|c|}
\hline \multirow{3}{*}{$\begin{array}{l}\text { Working style } \\
\text { Hurry Up }\end{array}$} & \multicolumn{3}{|c|}{$\begin{array}{c}\text { Group } 1 \\
\text { Economists }\end{array}$} & \multicolumn{3}{|c|}{$\begin{array}{c}\text { Group } 2 \\
\text { Legal Advisors }\end{array}$} & \multicolumn{2}{|c|}{ F - test } & \multicolumn{3}{|c|}{ t-test } \\
\hline & N1 & M1 & SD1 & N2 & M2 & SD2 & $F$ & $\mathrm{p}$ & t-test & $d f$ & $p$ \\
\hline & 30 & 24 & 4.84 & 30 & 23 & 5.02 & 0.004 & $p>0.05$ & 0.89 & 58 & $p>0.05$ \\
\hline & \multicolumn{3}{|c|}{$\begin{array}{l}\text { Group } 1 \\
\text { IT Experts }\end{array}$} & \multicolumn{3}{|c|}{$\begin{array}{c}\text { Group } 2 \\
\text { Legal Advisors }\end{array}$} & \multicolumn{2}{|c|}{$F$ - test } & \multicolumn{3}{|c|}{ t-test } \\
\hline \multirow{3}{*}{$\begin{array}{l}\text { Working style } \\
\text { Hurry Up }\end{array}$} & N1 & M1 & SD1 & N2 & M2 & SD2 & $\mathrm{F}$ & $p$ & t-test & $d f$ & $p$ \\
\hline & 30 & 22 & 3.88 & 30 & 23 & 5.02 & 1.75 & $p>0.05$ & 1.09 & 58 & $p>0.05$ \\
\hline & \multicolumn{3}{|c|}{$\begin{array}{c}\text { Group } 1 \\
\text { Economists }\end{array}$} & \multicolumn{3}{|c|}{$\begin{array}{l}\text { Group2 } \\
\text { IT Experts }\end{array}$} & \multicolumn{2}{|c|}{$F$ - test } & \multicolumn{3}{|c|}{ t-test } \\
\hline \multirow[t]{2}{*}{$\begin{array}{c}\text { Working style } \\
\text { Hurry Up }\end{array}$} & N1 & M1 & SD1 & N2 & M2 & SD2 & $\mathrm{F}$ & $p$ & t-test & $d f$ & $\mathrm{P}$ \\
\hline & 30 & 24 & 4.84 & 30 & 22 & 3.88 & 1.74 & $p>0.05$ & 2.12 & 58 & $p<0.05$ \\
\hline
\end{tabular}

Table 4: Analysis of the differences between the three professions regarding the working style Be Perfect

\begin{tabular}{|c|c|c|c|c|c|c|c|c|c|c|c|}
\hline \multirow{3}{*}{$\begin{array}{l}\text { Working style } \\
\text { Be Perfect }\end{array}$} & \multicolumn{3}{|c|}{$\begin{array}{c}\text { Group } 1 \\
\text { Economists }\end{array}$} & \multicolumn{3}{|c|}{$\begin{array}{c}\text { Group } 2 \\
\text { Legal Advisors }\end{array}$} & \multicolumn{2}{|c|}{ F - test } & \multicolumn{3}{|c|}{ t-test } \\
\hline & N1 & M1 & SD1 & N2 & M2 & SD2 & $F$ & $p$ & t-тест & $d f$ & $p$ \\
\hline & 30 & 30 & 4.41 & 30 & 27 & 5.06 & 0.41 & $p>0.05$ & 2.04 & 58 & $p<0.05$ \\
\hline & \multicolumn{3}{|c|}{$\begin{array}{l}\text { Group } 1 \\
\text { IT Experts }\end{array}$} & \multicolumn{3}{|c|}{$\begin{array}{c}\text { Group } 2 \\
\text { Legal Advisors }\end{array}$} & \multicolumn{2}{|c|}{ F - test } & \multicolumn{3}{|c|}{ t-test } \\
\hline \multirow{3}{*}{$\begin{array}{l}\text { Working style } \\
\text { Be Perfect }\end{array}$} & N1 & M1 & SD1 & N2 & M2 & SD2 & $\mathrm{F}$ & $p$ & t-тест & $d f$ & $p$ \\
\hline & 30 & 28 & 4.11 & 30 & 27 & 5.06 & 1.49 & $p>0.05$ & 0.39 & 58 & $p>0.05$ \\
\hline & \multicolumn{3}{|c|}{$\begin{array}{c}\text { Group } 1 \\
\text { Economists }\end{array}$} & \multicolumn{3}{|c|}{$\begin{array}{l}\text { Group2 } \\
\text { IT Experts }\end{array}$} & \multicolumn{2}{|c|}{ F - test } & \multicolumn{3}{|c|}{ t-test } \\
\hline \multirow{2}{*}{$\begin{array}{l}\text { Working style } \\
\text { Be Perfect }\end{array}$} & N1 & M1 & SD1 & N2 & M2 & SD2 & $\mathrm{F}$ & $p$ & t-тест & $d f$ & $p$ \\
\hline & 30 & 30 & 4.41 & 30 & 28 & 4.11 & 0.42 & $p>0.05$ & 1.85 & 58 & $p<0.05$ \\
\hline
\end{tabular}

Table 5: Analysis of the differences between the three professions regarding the working style Please People

\begin{tabular}{|c|c|c|c|c|c|c|c|c|c|c|c|}
\hline \multirow{3}{*}{$\begin{array}{l}\text { Working style } \\
\text { Please People }\end{array}$} & \multicolumn{3}{|c|}{$\begin{array}{c}\text { Group } 1 \\
\text { Economists }\end{array}$} & \multicolumn{3}{|c|}{$\begin{array}{c}\text { Group } 2 \\
\text { Legal Advisors }\end{array}$} & \multicolumn{2}{|c|}{ F - test } & \multicolumn{3}{|c|}{ t-test } \\
\hline & N1 & M1 & SD1 & N2 & M2 & SD2 & $F$ & $p$ & t-тест & $d f$ & $p$ \\
\hline & 30 & 31 & 3.99 & 30 & 29 & 3.94 & 0.15 & $p>0.05$ & 1.86 & 58 & $p<0.05$ \\
\hline & \multicolumn{3}{|c|}{$\begin{array}{l}\text { Group } 1 \\
\text { IT Experts }\end{array}$} & \multicolumn{3}{|c|}{$\begin{array}{c}\text { Group } 2 \\
\text { Legal Advisors }\end{array}$} & \multicolumn{2}{|c|}{ F - test } & \multicolumn{3}{|c|}{ t-test } \\
\hline \multirow{3}{*}{$\begin{array}{l}\text { Working style } \\
\text { Please People }\end{array}$} & $\mathrm{N} 1$ & M1 & SD1 & N2 & M2 & SD2 & $\mathrm{F}$ & $p$ & t-тест & df & $p$ \\
\hline & 30 & 27 & 3.56 & 30 & 29 & 3.94 & 0.34 & $p>0.05$ & 2.47 & 58 & $p<0.01$ \\
\hline & \multicolumn{3}{|c|}{$\begin{array}{c}\text { Group } 1 \\
\text { Economists }\end{array}$} & \multicolumn{3}{|c|}{$\begin{array}{l}\text { Group2 } \\
\text { IT Experts }\end{array}$} & \multicolumn{2}{|c|}{ F - test } & \multicolumn{3}{|c|}{ t-test } \\
\hline \multirow{2}{*}{$\begin{array}{l}\text { Working style } \\
\text { Please People }\end{array}$} & N1 & M1 & SD1 & N2 & M2 & SD2 & $F$ & $p$ & t-тест & df & $p$ \\
\hline & 30 & 31 & 3.99 & 30 & 27 & 3.56 & 0.01 & $p>0.05$ & 4.41 & 58 & $p<0.01$ \\
\hline
\end{tabular}


Table 6: Analysis of the differences between the three professions regarding the working style Try Hard

\begin{tabular}{|c|c|c|c|c|c|c|c|c|c|c|c|}
\hline \multirow{3}{*}{$\begin{array}{l}\text { Working style } \\
\text { Try Hard }\end{array}$} & \multicolumn{3}{|c|}{$\begin{array}{c}\text { Group } 1 \\
\text { Economists }\end{array}$} & \multicolumn{3}{|c|}{$\begin{array}{c}\text { Group } 2 \\
\text { Legal Advisors }\end{array}$} & \multicolumn{2}{|c|}{ F - test } & \multicolumn{3}{|c|}{ t-test } \\
\hline & N1 & M1 & SD1 & N2 & M2 & SD2 & $F$ & $p$ & t-тест & df & $\mathrm{p}$ \\
\hline & 30 & 28 & 4.85 & 30 & 24 & 5.82 & 1.07 & $p>0.05$ & 3.16 & 58 & $p<0.01$ \\
\hline & \multicolumn{3}{|c|}{$\begin{array}{l}\text { Group } 1 \\
\text { IT Experts }\end{array}$} & \multicolumn{3}{|c|}{$\begin{array}{c}\text { Group } 2 \\
\text { Legal Advisors }\end{array}$} & \multicolumn{2}{|c|}{ F - test } & \multicolumn{3}{|c|}{ t-test } \\
\hline \multirow{3}{*}{$\begin{array}{l}\text { Working style } \\
\text { Try Hard }\end{array}$} & N1 & M1 & SD1 & N2 & M2 & SD2 & $F$ & $p$ & t-тест & df & $p$ \\
\hline & 30 & 26 & 3.4 & 30 & 24 & 5.82 & 8.06 & $p<0.01$ & 2.04 & 58 & $p<0.05$ \\
\hline & \multicolumn{3}{|c|}{$\begin{array}{c}\text { Group } 1 \\
\text { Economists }\end{array}$} & \multicolumn{3}{|c|}{$\begin{array}{l}\text { Group2 } \\
\text { IT Experts }\end{array}$} & \multicolumn{2}{|c|}{ F - test } & \multicolumn{3}{|c|}{ t-test } \\
\hline \multirow{2}{*}{$\begin{array}{r}\text { Working style } \\
\text { Try Hard }\end{array}$} & N1 & M1 & SD1 & N2 & M2 & SD2 & $F$ & $p$ & t-тест & df & $p$ \\
\hline & 30 & 28 & 4.85 & 30 & 26 & 3.4 & 3.53 & $p>0.05$ & 1.75 & 58 & $p<0.05$ \\
\hline
\end{tabular}

Table 7: Analysis of the differences between the three professions regarding the working style Be Strong

\begin{tabular}{|c|c|c|c|c|c|c|c|c|c|c|c|}
\hline \multirow{3}{*}{$\begin{array}{l}\text { Working style } \\
\text { Be Strong }\end{array}$} & \multicolumn{3}{|c|}{$\begin{array}{c}\text { Group } 1 \\
\text { Economists }\end{array}$} & \multicolumn{3}{|c|}{$\begin{array}{c}\text { Group } 2 \\
\text { Legal Advisors }\end{array}$} & \multicolumn{2}{|c|}{ F - test } & \multicolumn{3}{|c|}{ t-test } \\
\hline & N1 & M1 & SD1 & N2 & M2 & SD2 & $\mathrm{F}$ & $p$ & t-тест & df & $\mathrm{p}$ \\
\hline & 30 & 23 & 4.46 & 30 & 24 & 4.37 & 0.38 & $p>0.05$ & 0.79 & 58 & $p>0.05$ \\
\hline & \multicolumn{3}{|c|}{$\begin{array}{l}\text { Group } 1 \\
\text { IT Experts }\end{array}$} & \multicolumn{3}{|c|}{$\begin{array}{c}\text { Group } 2 \\
\text { Legal Advisors }\end{array}$} & \multicolumn{2}{|c|}{ F - test } & \multicolumn{3}{|c|}{ t-test } \\
\hline \multirow{3}{*}{$\begin{array}{l}\text { Working style } \\
\text { Be Strong }\end{array}$} & N1 & M1 & SD1 & N2 & M2 & SD2 & $F$ & $p$ & t-тест & df & $\mathrm{p}$ \\
\hline & 30 & 24 & 3.67 & 30 & 24 & 4.37 & 2.66 & $p>0.05$ & 0.47 & 58 & $p>0.05$ \\
\hline & \multicolumn{3}{|c|}{$\begin{array}{c}\text { Group } 1 \\
\text { Economists }\end{array}$} & \multicolumn{3}{|c|}{$\begin{array}{l}\text { Group2 } \\
\text { IT Experts }\end{array}$} & \multicolumn{2}{|c|}{ F - test } & \multicolumn{3}{|c|}{ t-test } \\
\hline \multirow{2}{*}{$\begin{array}{l}\text { Working style } \\
\text { Be Strong }\end{array}$} & N1 & M1 & SD1 & N2 & M2 & SD2 & $F$ & $p$ & t-тест & df & $p$ \\
\hline & 30 & 23 & 4.46 & 30 & 24 & 3.67 & 0.65 & $p>0.05$ & 0.41 & 58 & $p>0.05$ \\
\hline
\end{tabular}

value of the t-test is calculated with the formula that assumes heterogeneous variances.

The values of the t-tests indicate that a statistically significant difference was found between the arithmetic means of the employees in the professions Economists and Legal Advisors, between the employees in the professions IT Experts and Legal Advisors and between Economists and IT Experts $(t=3.16, d f=58, p<0.01$; $t=2.04, d f=58, p<0.05 ; t=1.75, d f=58, p<0.05)$.
Be Strong

In Table 7 it can be seen that for Be Strong $\mathrm{F}$ does not exceed the critical value for 58 degrees of freedom at the level of $95 \%$, i.e. $p>0.05$, for all three combinations of groups, which indicates that the variance of the groups is homogenous and t-test can be used.

The values of the t-tests indicate that a statistically significant difference was found between the arithmetic means of the employees in the professions Economists 
and Legal Advisors, between the employees in the professions IT Experts and Legal Advisors and between Economists and IT Experts $(t=0.79, d f=58, p>0.05$; $t=0.47, d f=58, p>0.05 ; t=0.41, d f=58, p>0.05$ ).

\section{Discussion}

The analyses indicate the following implications concerning the matching of working style characteristics in the three professions covered by this survey with the way they are defined in the NNPM.

The Please People working style is the primary dominant style of the employees in the professions Economist and Legal Advisor, but not of the IT Experts. This tends to support the tasks in the job description of Economists and Legal Advisors including "focus on helping others"; the professions are defined in the NNPM as "Economists ... are giving advice to business - economic and other groups ... ", "Legal Advisors are giving legal advice to clients ..."

In contrast, IT Experts are more focused on information processing rather than interacting with people "... explore, plan, design, test, promote and develop principles and operational work methods... ". This again supports the presence of Be Perfect as the primary dominant working style of the employees in this profession, which is characterized by referring to the driver (Kahler, 2006) as having strong logic, organising skills and ability to recognize and synthesize facts. Please People, as secondary dominant working style, is still present among employees in this profession because ultimately their work brings products that make life easier for other people.

The Be Perfect working style is also one of the primary working styles of the Economists, which coincides with the need to "... do research, control data, analyse information and prepare reports and plans in order to address the current economic and business problems, develop models for analysing, explaining and predicting economic trends and patterns ... " (NNPM)

The Be Perfect working style is a secondary dominant working style of the Legal Advisors included in this research. This relates to the nature of their work which requires interpretation and representation of high moral principles. More than analysis and processing of information, one of the main features of individuals with a dominant working style Be Perfect is complying with high ethical standards (Žanko, 1999).

The Try Hard working style is a secondary dominant style of the Economists and IT Experts included in this research. The characteristics of this working style, as success in problem solving, monitoring all possibilities and finding all the implications and addressing all aspects of the task including what others missed (Hay, 1993/2009), are consistent with the definition of the profession of Economists "... develop models to analyse, explain and predict economic trends and patterns ... formulating solutions to existing and predicted economic and business problems" (NNPM). The above mentioned characteristics also correspond to the job description of the profession IT Expert "... promote and develop principles and operational work methods in order to improve systems and concepts of information and communication technologies ... to achieve optimal performance and data security" (NNPM).

The Try Hard working style is not present at all as a dominant working style in the profession Legal Advisor. It could be explained by the clearly established principles within the profession in the form of laws and regulations which does not require finding new and innovative solutions. On the other hand, it is quite common for the profession IT Experts, where Try Hard is present as a secondary dominant working style.

Taking the above into account, the question arises of whether people choose their professions because of their personality characteristics or whether the nature of the profession develops such personality characteristics or maybe strengthens them. The first view seems more likely: Wicklein \& Rojewski (1995) explored the relationship between psychological personality types and professional orientation among teachers of technological sciences and found, consistent with findings from previous researches in this area, that teachers with high scores on the scale of sensitivity (sensing, S) teach more practical courses, and teachers with high scores on the scale of intuition (intuition, $N$ ) teach more theoretical courses.

The second implication concerns the applicability of the concept of dominant working styles in different areas of human resources management. Within the professional selection of staff, the concept of working styles can be used as a tool for verifying the presence of the necessary skills and abilities in accordance with the job qualification. Kahler (2013) has used PCM (in which the basis are the drivers) in the selection of astronauts for NASA (National Aeronautics and Space Administration) for more than 10 years.

The concept of working styles is also applicable in the field of employee motivation. Kahler (2006) summarizes the incentive strategies that can be used to direct people towards optimal performance. Hay (1993/2009) also provides suggestions on motivation via stroke preferences, channels of communication and leadership styles.

\section{Limitations}

The nature of the sample means that the results are specific to certain occupational groups in Macedonia and may not apply elsewhere. This limitation is compounded because the original English questionnaire was 
translated into Macedonian, so may no longer be comparable with versions in English or other translations. However, the procedure and results may serve as a starting point for a broader analysis of the research problem.

It is likely that it will be beneficial to use the concept of working styles in combination with other selective methods. As confirmed through literature, combined selective methods have the greatest predictive power (Armstrong, 2005).

The limitation which is brought by the use of psychological personality characteristics to explain organizational behaviour and manage human resources must also be taken as a limitation of this study. Firstly, possible tendencies for stereotyping and categorizing based on psychological tests scores should be taken into consideration and personality characteristics should be understood as "... an individual preferred style of approaching and dealing with the world" (Wicklein \& Rojewski 1995; p.71).

Secondly, for a deeper understanding of the complexities of the personality in an organizational context, it is necessary to include more variables beside personality traits.

Although the completion of the questionnaire was voluntary, participants may not have believed this because they were due to attend a training programme to be run by the author and consultant. Hence, they may have been concerned that a refusal might lead to relationship issues during the training programme. This might have been especially the case for those participants whose primary working style was Please People. It might also have meant that participants responded in ways they thought would be most acceptable to the trainer and counsellor.

Issues that are not addressed in this study and whose answers can be used for a deeper understanding of the subject of research are: Are people whose dominant working styles overlap with dominant styles represented in their profession more successful in their work performance? Do they have greater job satisfaction and motivation? Are they less likely to leave their workplace?

\section{Conclusions}

Based on the results of this study, the general hypothesis that there is a difference between the dominant working styles among employees in the professions Economist, Legal Advisor and IT Expert is accepted.

Marina Pavlovska can be contacted on marinapavlovska@yahoo.com

The author wishes to thank Stanislav Petkovski, Certified Transactional Analyst (Psychotherapy) for being the consultant for this work.

\section{References}

Armstrong, M. (2005). A handbook of human resource management practice, 10th edition. London and Philadelphia: Kogan Page

Clarkson, P (1992) Physis in Transactional Analysis Transactional Analysis Journal 22:4 202-209

Gellert, S (1975) Drivers Transactional Analysis Journal 5:4 422-429

Hay, J. (1992) Transactional analysis for trainers. Minneapolis USA: Sherwood Publishing

Hay, J (1993/2009 $2^{\text {nd }}$ edn) Working it Out at Work Hertford: Sherwood Publishing

Hay, J. \& Williams, N. (1989) The Reluctant Time Manager, Opportunities May

Kahler T (1974) The miniscript Transactional Analysis Journal 4: 1, 26-42

Kahler, T. (1975). Drivers - The Key to the Process Script. Transactional Analysis Journal, 5:3

Kahler, T. (1979).Process therapy in brief. Little Rock: Human Development Publications

Kahler, T. (1982).Process Communication Model. Little Rock: Kahler Communications

Kahler, T. (2006). The Mastery of Management, or how to solve the mystery of mismanagement, 6th edition. Arkansas: Kahler Communications Inc.

Kahler, T. 2008 The Process Therapy Model: The Six Personality Types with Adaptations USA: Taibi Kahler Associates

Kahler, T (2013)

http://www.kahlercommunications.com/aresearch.html

Accessed 24 June 2013

Kahler, T. \& Capers, H. (1974).The Miniscript. Transactional Analysis Journal, 4: $126-42$

Klein, M. (1987) How to Be Happy Though Human Transactional Analysis Journal 17:4 152-162

Mescavage, A. \& Silver, C. (1977) "Try Hard" and "Please Me" in Psychological Development Transactional Analysis Journal 7:4 331-334

Ohlsson, T. (2010). Scientific evidence base for transactional analysis in the year 2010: Annex 1 - the Big List: References to Transactional Analysis research 1963- 2010. International Journal of Transactional Analysis Research, 1:1

State Statistical Office (2011) Државниот завод за статистика на Република Македонија. Националната номенклатура на занимања. Скопје: Државен завод за статистика на РепубликаМакедонија

Tudor, K. (2008) "Take It": A Sixth Driver Transactional Analysis Journal 38:1 43-57

Wicklein, R. \& Rojewski, J. (1995).The relationship between psychological type and professional orientation among technology education teachers. Journal of Technology Education 7:1

Žanko, N. (1999). Osnove transakcijske analize. Zagreb: Alinea 